\title{
Hybrid sterility in crosses between two Brazilian sibling species of the Anopheles albitarsis complex
}

\author{
Nathalia Giglio Fontoura', Alejandra Saori Araki ${ }^{2}$, Renata Van Der Maas Azevedo ${ }^{2}$, Allan Kardec Ribeiro Galardo ${ }^{3}$, \\ Alexandre Afranio Peixoto ${ }^{2^{\wedge}}$ and José Bento Pereira Lima ${ }^{1,4^{*}}$
}

\begin{abstract}
Background: Complexes of cryptic species are common in several taxa and this is also the case in the Anopheles genus, a group including all known human malaria vectors. The Anopheles albitarsis complex comprises at least nine cryptic species, some of which are implicated as vectors of human malaria. Several different types of data have been generated for this species complex such as cytogenetics, alloenzymes, morphological and feeding behavioral, hybridization experiments, RAPD-PCR and RFLP and mitochondrial and nuclear markers. Studies focused on its postzygotic isolation are still somewhat rare in the literature despite their importance to understand the speciation process and the level of gene flow potentially occurring among the different sibling species.

Methods: Hybridization experiments between Anopheles albitarsis s.s. and Anopheles marajoara, as well as backcrosses between hybrids and Anopheles albitarsis s.s., were performed using the induced mating technique. Results were compared to intraspecific crosses. Larva-to-adult viability and sex ratio were also assessed.

Results: Male hybrids show very low insemination rates and nearly complete sterility, apparently due to abnormalities in their reproductive organs. Evidence of partial sterility among the hybrid females was also observed.

Conclusions: Our data indicated that Anopheles albitarsis s.s. and Anopheles marajoara show a high level of postzygotic isolation with a strong hybrid male sterility. This result is consistent with the Haldane's rule which states that in interspecific crosses the heterogametic sex is the first to be affected. However, the fact that the females are not completely sterile raises the possibility of introgression between these two siblings species.
\end{abstract}

Keywords: Anopheles albitarsis complex, Anopheles albitarsis s.s, Anopheles marajoara, Hybrid sterility, Haldane's rule, Malaria, Speciation

\section{Background}

Complexes of cryptic species are common in several taxa $[1,2]$ and this is the case in the Anopheles genus, a group including all known human malaria vectors $[3,4]$. A better understanding of cryptic species can be epidemiologically relevant since it could offer clues about differential vector capacity (reviewed in [5]).

Anopheles albitarsis s.l. Lynch-Arribálzaga is widely distributed from northern Guatemala to northern Argentina [6] and is a complex of cryptic species that includes some

\footnotetext{
* Correspondence: jbento@ioc.fiocruz.br

Deceased

'Laboratório de Fisiologia e Controle de Artrópodes Vetores, Instituto Oswaldo Cruz, FIOCRUZ, Rio de Janeiro, Brasil

${ }^{4}$ Laboratório de Entomologia, Instituto de Biologia do Exército, Rio de Janeiro, RJ, Brasil

Full list of author information is available at the end of the article
}

of the most important regional vectors in America [7-9]. The first indication of An. albitarsis s.l. occurring as a species complex was described by Kreutzer et al. [10]. Since then, several approaches were applied to investigate and characterize the species members: cytogenetics, alloenzymes, morphological and feeding behavioral analysis, hybridization experiments, RAPD-PCR and RFLP and DNA sequencing of mitochondrial and nuclear markers [6,10-20].

Current knowledge suggests that the An. albitarsis complex comprises at least nine species: (i) An. albitarsis s.s. Lynch-Arribálzaga or An. albitarsis A, found in Argentina, Paraguay and Brazil (States of Bahia, Paraná, Santa Catarina, and São Paulo); (ii) Anopheles oryzalimnetes Wilkerson \& Motoki or An. albitarsis B, widespread in Paraguay and probably the species with the wider geographical 
distribution in Brazil (States of Bahia, Ceará, Espírito Santo, Mato Grosso, Pará, Paraná, Rio de Janeiro and São Paulo); (iii) Anopheles marajoara Galvão \& Damasceno or An. albitarsis C, found in Paraguay, Venezuela and in Brazil (States of Amapá, Amazonas, Mato Grosso, Pará, Rondônia and São Paulo); (iv) Anopheles deaneorum Rosa-Freitas or An. albitarsis D, distributed in northern Argentina and in Brazil (States of Acre, Mato Grosso, Paraná and Rondônia); (v) Anopheles janconnae Wilkerson \& Sallum or An. albitarsis E, found in northern Brazil (States of Amapá, Pará and Roraima) and in Venezuela; (vi) An. albitarsis F, in Colombia, Venezuela and Trinidad; (vii) An. albitarsis G, exclusive to Brazil (States of Amazonas, Bahia and Pará); (viii) An. albitarsis $\mathrm{H}$, also restricted to Brazil (States of Mato Grosso and Rondônia); and (ix) $A n$. albitarsis I, found in Colombia and Venezuela [9,17,20-24]. Moreover, the number of species within the Anopheles albitarsis complex can be even higher as An. deaneorum and $A n$. marajoara might include more than one sibling species $[9,25]$.

In an evolutionary context, analysis of the reproductive isolation between cryptic species of insect vectors allows the identification of potential gene flow among siblings. In addition, laboratory crossing experiments are likely to reveal the exchange of genes potentially involved in vectorial capacity or insecticide resistance, being therefore important for vector control programs [16,26-28]. In the Albi tarsis species complex only two hybridization studies between siblings have been published so far [16,29]. This is probably due to the difficulty of keeping these species in captivity, since neotropical Anopheles albitarsis species rarely perform free mating crosses under laboratory conditions. In 1991, Klein et al. [29] observed male hybrid sterility in crosses between $A n$. deaneorum and a species that they called "B", later defined as An. marajoara (Richard C. Wilkerson, personal communication). In the second study, Lima et al. [16] observed that hybrid males from crosses between An. albitarsis s.s. and An. deaneorum showed very low insemination rates and suggested that the abnormalities in their reproductive organs could explain this. In the present work, we performed crossing experiments between two Brazilian sibling species of the An. albitarsis complex, An. albitarsis s.s. and An. marajoara. We used these two species in order to analyze the degree of reproductive isolation between them and compare with previous ones. The present work represents an interesting study from an evolutionary point of view of An. albitarsis complex and is epidemiologically relevant focusing a Neotropical malaria vector such as $A n$. marajoara.

\section{Methods}

\section{Mosquito samples}

We analyzed specimens of An. albitarsis s.s. from a colony maintained at the Instituto de Biologia do Exército
(Rio de Janeiro State, Brazil) following the protocol described by Horosko et al. [30] with slight modifications. The colony was established in 1993 with mosquitoes collected from Massaranduba municipality $\left(26^{\circ} 36^{\prime} 39^{\prime \prime}\right.$ S, 49 0' 33" W) (Santa Catarina State, Brazil) [16]. This species was treated as a control in crosses since the specimens used were obtained from a stable colony [16]. In addition, An. marajoara females were collected in Mazagão municipality ( $\left.0^{\circ} 6^{\prime} 58^{\prime \prime} \mathrm{S}, 51^{\circ} 17^{\prime} 10^{\prime \prime} \mathrm{W}\right)$ (Amapá State, Brazil). Specimens were identified as Anopheles albitarsis s.l. according to Faran \& Linthicum [31] and were considered as An. marajoara based on Conn et al. [7]. The identification was then confirmed by DNA barcoding (see below). Laboratory rearing of $A n$. marajoara was performed according to Lima et al. [16]. The An. marajoara specimens belonging to F1-F3 generations were used in crossing experiments. All procedures were carried out under controlled conditions: $27^{\circ} \mathrm{C}$ for the immature stages (larvae to pupae) and $25^{\circ} \mathrm{C}$ and $70 \%$ relative humidity for the adult mosquitoes.

\section{Identification by DNA barcoding}

DNA barcodes (658 bp of the mtDNA Cytochrome c Oxidase - COI) were generated for $11 \mathrm{An}$. albitarsis s.s. and 12 An. marajoara specimens (Accession numbers: KM391793 to KM391815). DNA extraction was carried out as in Jowett [32] and PCR amplification using the LCO1490 and HCO2198 primers of Folmer et al. [33]. Sequencing reactions were carried out in both directions with the Big Dye Terminator Kit and ABI 3730 automated sequencer (PE Applied Biosystems). Sequences were edited in Bioedit 7.2.3 [34] and the delineation of species within Albitarsis group by phylogenetic analysis was carried out using specimens from each distinctive COI lineage found by NJ-K2P analysis. The sequences added were: An. albitarsis H: GenBank: DQ076222, DQ076223, DQ076224; An. deaneorum: GenBank: DQ076226, DQ07 6227, DQ076229, DQ076230; An. albitarsis G: GenBank: DQ076221, DQ076225; An. oryzalimnetes: GenBank: DQ076210, DQ076211, DQ076213, DQ0762105. We used the Kimura-two-parameter distance model (K2P), Neighborjoining analysis $(\mathrm{NJ})$ and 1,000 replicates to produce an unrooted consensus tree.

\section{Crossing experiments}

Methods for crossing experiments were performed as described in Lima et al. [16]. Males and females were separated every twelve hours to guarantee the collection of virgin females [35]. Females were fed according to the protocol approved by the Fiocruz Ethical Committee on Use of Animals (CEUA) and subjected to the artificialmating technique [36]. Four days after mating, the females were placed in a plastic device $(8.5 \mathrm{~cm}$-diameter $\times 4.5 \mathrm{~cm}$ depth) closed with a nylon mesh and submerged in a bowl 


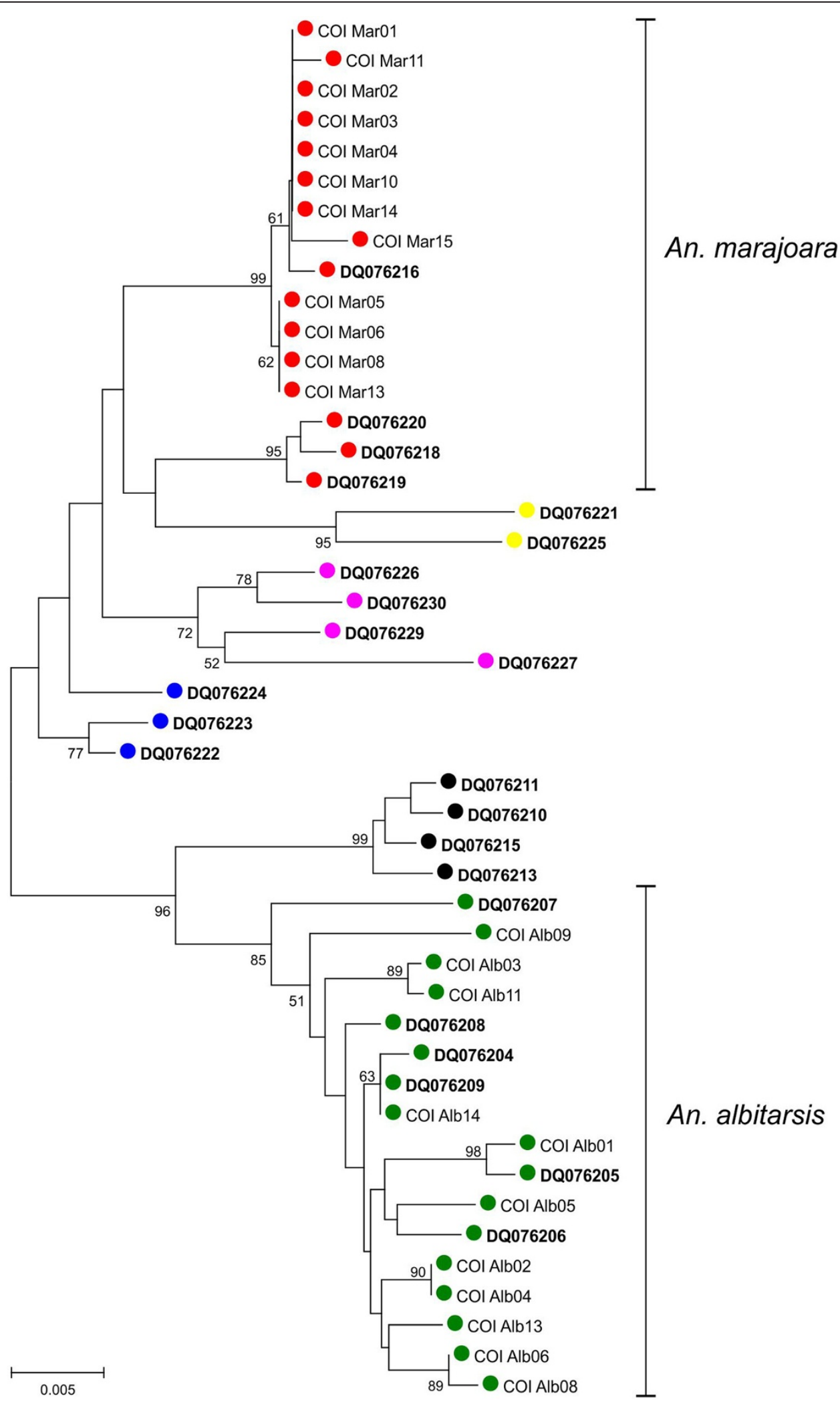

Figure 1 Phylogenetic tree generated using GeneBank sequences and specimens of An. marajoara and An. albitarsis s.s. The lineages are represented in different colors: 1) An. albitarsis $\mathrm{H}$ in blue, 2) An. deaneorum in pink; 3) An. albitarsis G in yellow; 4) An. oryzalimnetes in black; 5) An. albitarisis s.s. in green and 6) An. marajoara in red. Bootstrap values were obtained with 1,000 permutations. Only values above $50 \%$ are shown. 
(18 cm-diameter $\times 7.5 \mathrm{~cm}$-depth) filled with dechlorinated water. The internal surface of the plastic device was covered with moist filter paper to keep eggs from drying out. After two days, the spermathecae (from alive and dead females) were dissected and examined by light microscopy; mating success was scored based on the presence of sperm.

Eggs were counted after forced egg laying. Two days after hatching, larvae were counted and transferred to water-filled plastic bowls. Every two days numbers of larvae and living pupae were counted. The immature stages were reared following the same protocol already mentioned for the colony maintenance. Adults were used in the subsequent crosses. Intra and interspecific mating experiments were performed and the hybrid offspring were used in backcrosses according to Lima et al. [16]. The parameters evaluated for each crossing experiment were: the number of inseminated females, the total number of eggs, hatching eggs, larvae, pupae and adults, and also the male and female ratio.

\section{Evaluation of the male genital apparatus}

Male genital structures of the offspring were dissected and examined using stereoscopy microscopy. External and internal genital structures were mounted in slides with saline solution, and in some cases, were stained using the buffer reference standard $\mathrm{pH}=4.0$ (Sigma) for a better visualization. Chi-square statistical analysis was estimated by the program GraphPad Prism 5.0 [37].

\section{Results}

\section{DNA barcoding}

Figure 1 shows a phylogenetic tree with six clusters clearly defined: 1) An. albitarsis $\mathrm{H}$; 2) An. deaneorum; 3) An. albitarsis G; 4) An. oryzalimnetes; 5) An. albitarisis s.s. and 6) An. marajoara. The latter group included all individual sequences of $A n$. marajoara showing that we used a pure lineage on our crossing experiments.

\section{Viability assessment}

Table 1 shows larvae-to-adult viability of the offspring from intraspecific and interspecific crosses between An. albitarsis s.s. and An. marajoara, and also backcrosses of these hybrids with $A n$. albitarsis s.s.. In each case, eight different crosses were conducted. The hatching number from the different groups of crosses was highly variable. The two intraspecific and the interspecific crosses between male An. marajoara $\times$ female An albitarsis s.s. showed very similar hatching percentages (ranged between 38\% and 45\%). Nevertheless, a remarkable reduction on hatching rates was observed in all backcrosses. Furthermore, crosses between hybrid males and An. albitarsis s.s. females resulted in null or near to zero rates. In general, the pupation was a more homogeneous developmental event than hatching. A significant reduction of the larvae viability was observed in crosses that involved females of $A n$. marajoara, in conspecific crosses of An. marajoara $\left(X^{2}=26.34, \mathrm{df}=1, P<0.001\right)$ and male $A n$. albitarsis s.s. $\times$ female $A n$. marajoara $\left(X^{2}=\right.$ $4.48, \mathrm{df}=1, P=0.034)$. Differing from the dramatically decreased hatching in backcrosses, pupation and adult emergence seemed unaffected when hybrid females were used. Intraspecific and interspecific crosses also resulted in similar and high percentages of emergence. Finally, we observed that in all cases the sexual ratio was not statistically different from 1:1 indicating similar mortality between genders.

\section{Evaluation of insemination}

After oviposition, the eggs were counted and the spermathecae dissected and classified as positive or negative

Table 1 Larvae-to-adult viability of the intraspecific offprings and hybrids between species of the Anopheles albitarsis complex

\begin{tabular}{|c|c|c|c|c|c|c|c|c|}
\hline Crosses & $\begin{array}{l}\text { Total of } \\
\text { eggs } \mathrm{N}\end{array}$ & $\begin{array}{l}\text { Hatching } \\
\mathrm{N}(\%)\end{array}$ & $\begin{array}{l}\text { Pupation } \\
\text { N (\%) }\end{array}$ & $\begin{array}{l}\text { Adult emergence } \\
\mathrm{N}(\%)\end{array}$ & Alive (\%) & Males N (\%) & Females N (\%) & M/F ratio \\
\hline \multicolumn{9}{|l|}{ Intraspecific } \\
\hline$\precsim \mathrm{ALB} \times q \mathrm{ALB}$ & 2128 & $887(41.7)$ & $475(53.6)$ & $392(82.5)$ & $(44.2)$ & $192(49.0)$ & $200(51.0)$ & 0.96 \\
\hline$\delta M A R \times q M A R$ & 2733 & 1048 (38.3) & $258(24.6)^{* * *}$ & $204(79.1)$ & $(19.5)$ & $85(41.7)$ & $119(58.3)$ & 0.71 \\
\hline \multicolumn{9}{|l|}{ Interspecific } \\
\hline$\delta \mathrm{ALB} \times q \mathrm{MAR}$ & 3812 & $2194(57.6)^{* * *}$ & $861(39.2)^{*}$ & $740(85.9)$ & $(33.7)$ & $404(54.6)$ & $336(45.4)$ & 1.20 \\
\hline$\delta M A R \times q A L B$ & 2352 & 1057 (44.9) & $555(52.5)$ & $406(73.2)$ & $(38.4)$ & $197(48.5)$ & $209(51.5)$ & 0.94 \\
\hline \multicolumn{9}{|l|}{ Backcrosses } \\
\hline$\delta \mathrm{ALB} \times$ qHybrid A & 1479 & $143(9.7)^{* * *}$ & $76(53.1)$ & $57(75.0)$ & (39.9) & $29(50.9)$ & $28(49.1)$ & 1.04 \\
\hline$\delta$ ALB $\times$ qHybrid B & 2489 & $210(8.4)^{* * *}$ & $111(52.9)$ & $78(70.3)$ & $(37.1)$ & $39(50.0)$ & $39(50.0)$ & 1.00 \\
\hline$\delta$ Hybrid $A \times q A L B$ & 1823 & 0 & 0 & 0 & 0 & 0 & 0 & 0 \\
\hline ôHybrid B $\times \stackrel{+}{ }$ ALB & 921 & $1(0.001)$ & 0 & 0 & 0 & 0 & 0 & 0 \\
\hline
\end{tabular}

$\mathrm{N}$, number; (\%), percentage in brackets; ALB, Anopheles albitarsis s.s.; MAR, Anopheles marajoara; Hybrid A: resulting of interspecific crosses between $\lesssim$ ALB $\times$, MAR; Hybrid B: resulting of interspecific crosses between ${ }^{\top} \mathrm{MAR} \times \Phi$ ALB.

${ }^{*} P<0.05$; ${ }^{* * *} P<0.001$. 
Table 2 Insemination rates in crosses between species of the Anopheles albitarsis complex and their reciprocal hybrids

\begin{tabular}{|c|c|c|}
\hline Crosses & Mated females $\mathrm{N}$ & Spermathecae $^{+} \mathrm{N}(\%)$ \\
\hline \multicolumn{3}{|l|}{ Intraespecific } \\
\hline$\partial^{\lambda} \mathrm{ALB} \times q \mathrm{ALB}$ & 125 & $65(52.0)$ \\
\hline OMAR $\times$ QMAR & 166 & $35(21.1)^{* *}$ \\
\hline \multicolumn{3}{|l|}{ Interspecific } \\
\hline$\sigma^{\lambda} \mathrm{ALB} \times \stackrel{+}{\mathrm{MAR}}$ & 168 & $76(45.2)$ \\
\hline$\sigma^{\top} \mathrm{MAR} \times O A L B$ & 195 & $35(17.9)^{* *}$ \\
\hline \multicolumn{3}{|l|}{ Backcrosses } \\
\hline${ }^{\lambda} \mathrm{ALB} \times$ q Hybrid A & 95 & $49(51.6)$ \\
\hline$\delta$ ALB $\times$ q Hybrid B & 111 & $55(49.5)$ \\
\hline$\sigma^{\top}$ Hybrid $A \times q A L B$ & 133 & $2(1.5)^{* * *}$ \\
\hline JHybrid $B \times q A L B$ & 98 & $6(6.1)^{* * *}$ \\
\hline
\end{tabular}

$\mathrm{N}$, number; (\%), percentage in brackets; ${ }^{+}$positive spermathecae (with sperm in its interior); ALB, Anopheles albitarsis s.S.; MAR, Anopheles marajoara; Hybrid A: resulting of interspecific crosses between $A L B \times$ MAR; Hybrid $B$ : resulting of interspecific crosses between ${ }^{\top} \mathrm{MAR} \times O$ ALB. ${ }^{* *} P<0.01$; ${ }^{* * *} P<0.001$. depending on the presence or lack of sperm, respectively. Females with positive spermathecae were considered inseminated. Table 2 shows the number of mated and positive females for each performed cross. As expected, a higher percentage of inseminated females was observed in crosses involving An. albitarsis s.s. males since they result from induced mating, which introduces a level of selection [38]. The low An. marajoara male effectiveness can be attributed to the use of F1 and F2 mosquito generations not adapted to laboratory conditions. The crosses with $A n$. marajoara males were really challenging, even compared with other Anopheline species, such as An. deaneorum. The number of inseminated females was significantly lower in crosses with hybrid males than with An. albitarsis s.s. In some cases, females mated with interspecific males showed immotile sperm or even agglomerated sperm with dark pigmentation (data not shown).

Figure 2 shows comparisons between different crosses using the normalized insemination rates estimated from Table 2 data. Normalization was carried out using results from the intraspecific cross of An. albitarsis s.s.. Figure 2A illustrates the normalized insemination rates involving females of different genotypes crossed to An. albitarsis s.s.

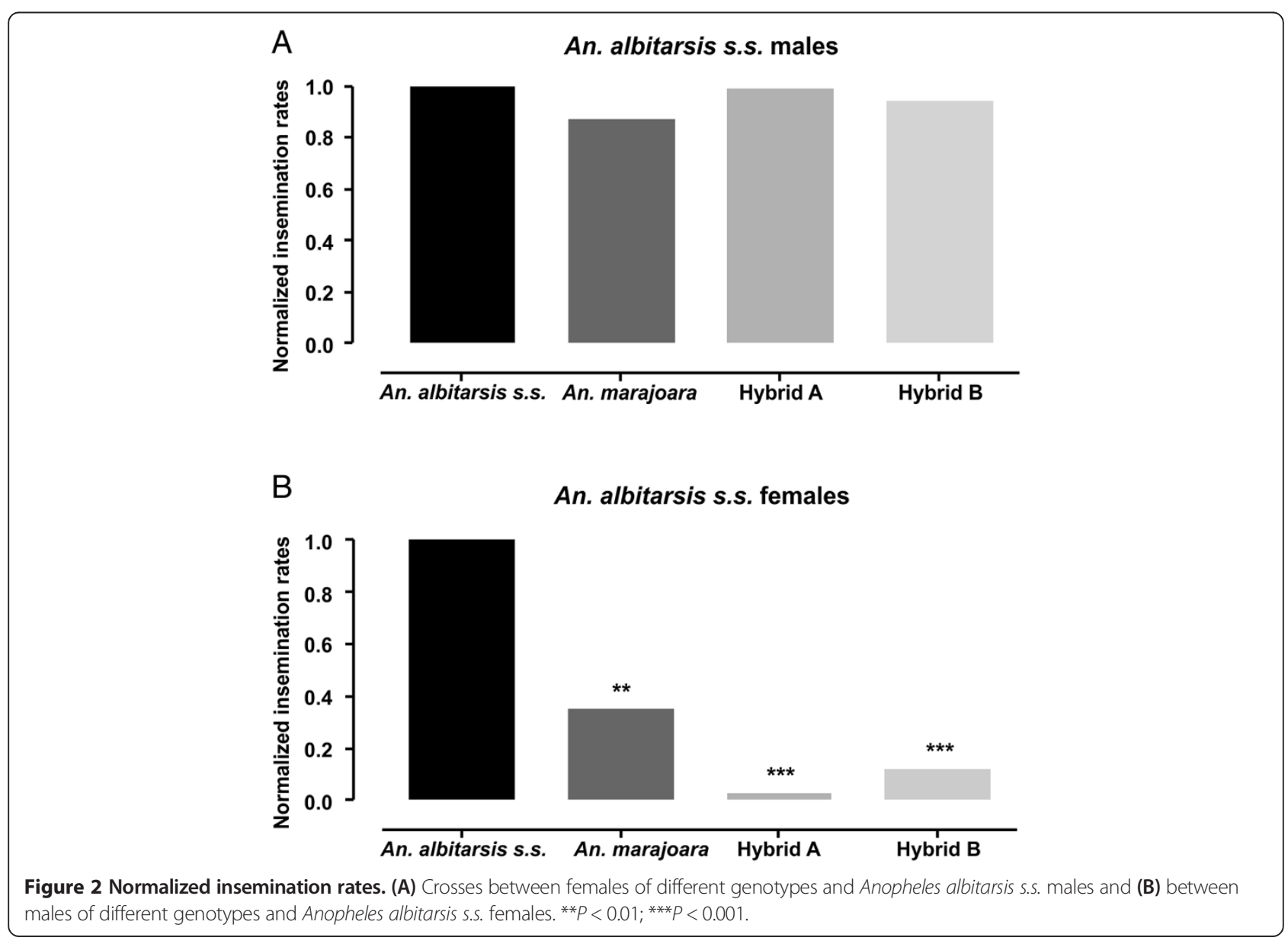


males. In all cases, the difference between female insemination rates was not significant, regardless of their genotype. The results observed for the two types of hybrid females were expected since they have a similar genotype. Figure $2 \mathrm{~B}$ shows the normalized insemination data of An. albitarsis s.s. females mated to males of different genotypes. Comparing to the intraspecific cross, a significant reduction of insemination rates was observed in all other crosses. Anopheles marajoara males inefficiently inseminate $A n$. albitarsis s.s. females $(P<0.01)$ and hybrid males performed even less successfully $(P<0.001)$. However, insemination rates of crosses using both types of hybrid males did not differ significantly. Although some females inseminated by hybrid males laid eggs, their viability was null (see Table 1 ).

Figure 3 shows the male reproductive organs of $A n$. albitarsis s.s. and An. marajoara (Figure $3 \mathrm{~A}$ and $\mathrm{B}$, respectively) and hybrids resulted from interspecific crosses (Figure 3C-E). Invariably, abnormalities were detected only in male hybrids. Malformations consisted of reduced testis with long and thin vas deferens (Figure 3C), abnormal testis with a lobular structure and a malformed and irregular vas deferens (Figure 3D) or fused testis with short vas deferens (Figure 3E).

\section{Discussion}

Variable patterns of reproductive isolation are observed between pairs of siblings of Anopheles species complexes. For example in the An. gambiae complex, two molecularly distinguished forms, known as $\mathrm{M}$ and $\mathrm{S}$, do not show reduction in hybrid males and females' viability or fertility. This result suggests that other mechanisms, apart from postzygotic developmental barriers [39], are acting in this speciation process. In this sense, it has been claimed that differences in wing-beat frequencies recognition plays a relevant role [40]. Hybridization between Anopheles minimus $\mathrm{A}$ and $\mathrm{C}$, from the An. minimus complex, results in fertile males and females with normal ovaries [41]. However, crosses between An. minimus A and E produce sterile males and normal females [42].

Concerning the postzygotic isolation mechanisms, the hybrid sterility seems to be one of the first outcomes observed in anophelines [16,29,42-46]. Crosses between An. albitarsis s.s. and An. marajoara produced viable hybrid offspring from both genders in normal rates suggesting the absence of prezygotic isolation mechanisms. However, our results point to a high degree of postzygotic reproductive isolation between these sibling species. The observed pattern of crosses fits the Haldane's rule, which states that in interspecific crosses the heterogametic sex shows sterility or viability problems before the homogametic one [47]. Eggs resulted from crosses involving hybrid males do not hatch at all. This indicates that the reproductive isolation is a consequence of males' sterility, possibly due to abnormalities in their reproductive
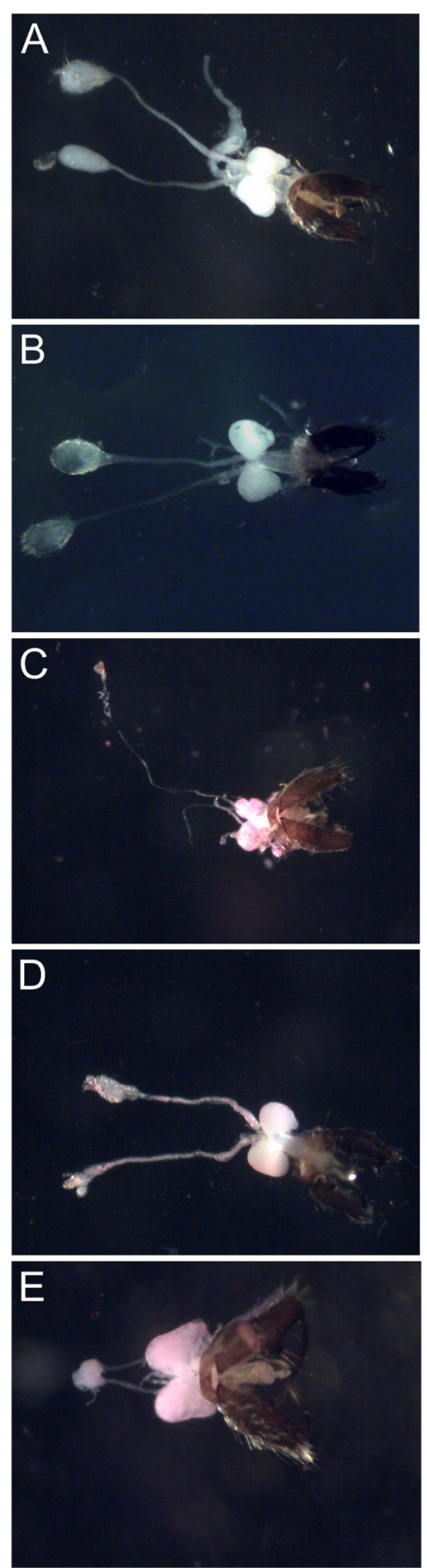

Figure 3 Male reproductive organs showed malformations on testis and vas deferens. (A) Anopheles albitarsis S.S., (B) Anopheles marajoara and (C-E) hybrids. 
organs. Although hybrid females exhibit a similar degree of insemination when compared to An. albitarsis s.s. control, the hatching percentage of their eggs also suggests postzygotic isolation. Moreover, this isolation phenomenon seems to have a lower effect in females than in males. Interestingly, the development rate of the hybrid females' offspring is comparable to the intraspecific An. albitarsis s.s. control. This indicates some degree of hybrid females' infertility, a potential further point of control of interspecific gene flow, at the embryonic stage. In the $A n$. albitarsis complex, previous analysis of reproductive isolation between An. albitarsis s.s. and An. deaneorum, also revealed postzygotic isolation due to sterility of hybrid males [16]. Differing from the present observations, those hybrid males exhibited different levels of sterility. In that case, hybrid males carrying an An. deaneorum X chromosome were the most affected. Moreover, An. deaneorum males were less successful in inseminating An. albitarsis s.s females than their conspecific females, whereas no significant difference was observed in the reciprocal cross. This result suggests that in areas where both species occur in sympatry, asymmetrical introgression might happen. This asymmetry in the hybrid sterility is frequent in interspecific crosses of closely related species [48]. In spite of that, our results suggest an established and effective barrier to this interspecific introgression considering the almost complete failure of both An. albitaris s.s. and $A n$. marajoara males. Further crossing experiments and studies of natural populations using molecular markers might help to determine the genetic relationships and the gene flow among siblings of the Albitarsis complex that includes some of the malaria vectors of America.

\section{Conclusions}

Our data confirm that An. albitarsis s.s. and An. marajoara are distinct species of the Albitarsis complex with a high degree of postzygotic reproductive isolation between them. Hybrid males show sterility probably caused by abnormalities in their reproductive organs and a subtle effect was observed in the hybrid females. This result is consistent with the Haldane's rule which states that in interspecific crosses the heterogametic sex is the first to be affected. The fact that the females are not completely sterile raises the possibility of introgression between these two siblings species.

\section{Competing interests}

The authors declare that they have no competing interests.

\section{Authors' contributions}

NGF and ASA performed crossing experiments and analysis, and drafted the manuscript. RVDMA participated in the data analysis and drafting the manuscript. AKRG was involved in the field collection. AAP and JBPL participated in the design of the study, data analysis, drafting the manuscript, general supervision of the research group and funding acquisition. All authors read and approved the final document.

\section{Acknowledgements}

We would like thank Robson Costa da Silva for technical assistance and Denise Valle for helpful advice and suggestions. This work was supported by grants from CNPq, CAPES and FIOCRUZ. We dedicate this manuscript to Alexandre Afranio Peixoto in memorian.

\section{Author details}

'Laboratório de Fisiologia e Controle de Artrópodes Vetores, Instituto Oswaldo Cruz, FIOCRUZ, Rio de Janeiro, Brasil. ' Laboratório de Biologia Molecular de Insetos, Instituto Oswaldo Cruz, FIOCRUZ, Rio de Janeiro, Brasil. ${ }^{3}$ Instituto de Pesquisas Científicas e Tecnológicas de Estado do Amapá,

Macapá, Amapá, Brasil. ${ }^{4}$ Laboratório de Entomologia, Instituto de Biologia do Exército, Rio de Janeiro, RJ, Brasil.

Received: 18 March 2014 Accepted: 23 November 2014

Published online: 04 December 2014

\section{References}

1. Bickford D, Lohman DJ, Sodhi NS, Ng PK, Meier R, Winker K, Ingram KK, Das I: Cryptic species as a window on diversity and conservation. Trends of Ecol Evol 2007, 22:148-155.

2. Pfenninger $M$, Schwenk K: Cryptic animal species are homogeneously distributed among taxa and biogeographical regions. BMC Evol Biol 2007 7:121

3. Sinka ME, Bangs MJ, Manguin A, Rubio-Palis Y, Chareonviriyaphap T, Coetzee M, Mbogo CM, Hemingway J, Patil AP, Temperley WH, Gething PW, Kabaria CW Burkot TR, Harbach RE, HaY SI: A global map of dominant malaria vectors. Parasit Vectors 2012, 5:69.

4. Otarigho B, Falade MO: Molecular evolution and phylogenomics of the Anopheles gambiae complex. J Mosq Res 2013, 3(9):65-70.

5. Ayala FJ, Coluzzi M: Chromosome speciation: humans, Drosophila, and mosquitoes. Proc Natl Acad Sci U S A 2005, 102:6535-6542.

6. Rosa-Freitas MG, Deane LM, Momen H: A morphological, isoenzymatic and behavioral study of ten populations of Anopheles (Nyssorhynchus) albitarsis Lynch-Arribalzaga, 1878 (Diptera: Culicidae) including from the Typelocality-Baradero, Argentina. Mem Inst Oswaldo Cruz 1990, 85:275-289.

7. Conn JE, Wilkerson RC, Segura MNO, De-Sousa RTL, Schlichting CD, Wirtz A Póvoa MM: Emergence of a new neotropical malaria vector facilitated by human migration and changes in land use. Am J Trop Med Hyg 2002, 66(1):18-22

8. Povoa MM, de Souza RTL, Lacerda RNL, Rosa ES, Galiza D, de Souza JR, Wirtz RA, Schlichting CD, Conn JE: The importance of Anopheles albitarsis E and Anopheles darlingi in humam malária transmission in Boa Vista state of Roraima, Brazil. Mem Inst Oswaldo Cruz 2006, 101:163-168.

9. Mckeon SN, Lehr MA, Wilkerson RC, Ruiz JF, Sallum MA, Lima JBP, Povoa MM, Conn JE: Lineage divergence detected in the malaria vector Anopheles marajoara (Diptera: Culicidae) in Amazonian Brazil. Malar J 2010, 9:271.

10. Kreutzer RD, Kitzmiller JB, Rabbani MG: Cytogenetically distinguishable sympatric and allopatric populations of the mosquito Anopheles albitarsis. Acta Amazon 1976, 6(4):473-481.

11. Rosa-Freitas MG, Deane LM: Anopheles (Nyssorhynchus) deaneorum: a new species in the albitarsis complex (Diptera: Culicidae). Mem Inst Oswaldo Cruz 1989, 84:289-302.

12. Narang SK, Klein TA, Perera OP, Lima JB, Tang AT: Genetic evidence for the existence of cryptic species in the Anopheles albitarsis complex in Brazil: allozymes and mitochondrial DNA restriction fragment length polymorphisms. Biochem Genet 1993, 31:97-112.

13. Wilkerson RC, Gaffigan TV, Lima JB: Identification of species related to Anopheles (Nyssorhynchus) albitarsis by random amplified polymorphic DNA-polymerase chain reaction (Diptera: Culicidae). Mem Inst Oswaldo Cruz 1995, 90(6):721-732.

14. Wilkerson RC, Parsons TJ, Klein TA, Gaffigan TV, Bergo E, Consolim J: Diagnosis by random amplified polymorphic DNA polymerase chain reaction of four cryptic species related to Anopheles (Nyssorhynchus) albitarsis (Diptera: Culicidae) from Paraguay, Argentina, and Brazil. J Med Entomol 1995, 32:697-704

15. Wilkerson RC, Foster PG, Li C, Sallum MAM: Molecular phylogeny of neotropical Anopheles (Nyssorhynchus) albitarsis species complex (Diptera: Culicidae). An Entomol Soc Amer 2005, 98:918-925.

16. Lima JBP, Valle D, Peixoto AA: Analysis of reproductive isolation between sibling species Anopheles albitarsis s.s. and Anopheles deaneorum, two 
malaria vectors belonging to the Albitarsis Complex (Diptera: Culicidae). J Med Entomol 2004, 41(5):888-893.

17. Li C, Wilkerson RC: Identification of Anopheles (Nyssorhynchus) albitarsis complex species (Diptera: Culicidae) using rDNA internal transcribed sapacer 2-based polymerase chain reaction primers. Mem Inst Oswaldo Cruz 2005, 100(5):495-500.

18. Li C, Wilkerson RC: Intragenomic rDNA ITS2 variation in the Neotropical Anopheles (Nyssorhynchus) albitarsis complex (Diptera: Culicidae). $J$ Heredity 2006, 98:51-59.

19. Merritt TJA, Young CR, Wilkerson RC, Quattro JM: Intron retention identifies a malaria vector within the Anopheles (Nysshorhynchus) albitarsis complex (Diptera: Culicidae). Mol Phyl and Evol 2005, 35:719-724.

20. Brochero HHL, Li C, Wilkerson RC: A newly recognized species in the Anopheles (Nyssorhynchus) albitarsis complex (Diptera: Culicidae) from Puerto Carreno. Colômbia Am J Trop Med Hyg 2007, 76(6):1113-1117.

21. Lehr MA, Kilpatrick CW, Wilkerson RC, Conn JE: Cryptic species in the Anopheles (Nyssorhynchus) albitarsis (Diptera: Culicidae) complex: incongruence between random amplified polymorphic DNA-Polymerase Chain Reaction identification and analysis of mitochondrial DNA COI gene sequences. Ann Entomol Soc Am 2005, 98(6):908-917.

22. Motoki MT, Wilkerson RC, Sallum MAM: The Anopheles albitarsis complex with the recognition of Anopheles oryzalimnetes Wilkerson and Motoki, n. sp. and Anopheles janconnae Wilkerson and Sallum, n. sp. (Diptera: Culicidae). Mem Inst Oswaldo Cruz 2009, 104(6):823-850.

23. Sinka ME, Rubio-Palis Y, Manguin S, Patil AP, Temperley WH, Gething PW Van Boeckel T, Kabaria CW, Harbach RE, Hay SI: The dominat Anopheles vectors of human malaria in the Americas: occurrence data, distribution maps and bionomic précis. Parasit Vectors 2010, 3:72.

24. Ruiz-Lopez F, Wilkerson RC, Conn JE, McKeon SN, Levin DM, Quiñones ML, Póvoa MM, Linton YM: DNA barcoding reveals both known and novel taxa in the Albitarsis Group (Anopheles: Nyssorhynchus) of Neotropical malaria vectors. Parasit Vectors 2012, 5:44

25. Bourke BP, Foster PG, Bergo ES, Calado DC, Sallum MA: Phylogenetic relationships among species of Anopheles (Nyssorhynchus) (Diptera: Culicidae) based on nuclear and mitochondrial gene sequences. Acta Trop 2010, 114:88-96.

26. Besansky NJ, Krzywinski J, Lehmann T, Simard F, Kern M, Mukabayire O, Fontenille D, Touré Y, Sagnon N: Semipermeable species boundaries between Anopheles gambiae and Anopheles arabiensis: Evidence from multilocus DNA sequence variation. Proc Natl AcadSci U S A 2003, 100:10818-10823.

27. Slotman MA, Della Torre A, Calzetta M, Powell JR: Differential introgression of chromosomal regions between Anopheles gambiae and An. arabiensis. Am J Trop Med Hyg 2005, 73:326-335.

28. Djogbénou L, Chandre F, Berthomieu A, Dabiré R, Koffi A, Alout H, Weill M: Evidence of introgression of the ace-1R mutation and of the ace-1 duplication in West African Anopheles gambiae s. s. PLoS One 2008, 3:e2172.

29. Klein TA, Lima JBP, Toda-Tang A: Hybridization evidence supporting separate especies status for Anopheles albitarsis and Anopheles deaneorum (Diptera: Culicidae) in Brazil. J Am Mosa Control Assoc 1991, 7:301-303.

30. Horosko S, Lima JBP, Brandolini MB: Establishment of a free mating colony of Anopheles albitarsis from Brazil. J Am Mosa Control Assoc 1997, 13:95-96.

31. Faran ME, Linthicum KJ: A handbook of the Amazon species of Anopheles (Nyssorhynchus) (Diptera: Culicidae). Mosq System 1981, 13:1-81.

32. Jowett T: Preparation of Nucleic Acids. In Drosophila: A Practical Approach Edited by Roberts DB. Oxford: IRL Press; 1998:347-371.

33. Folmer O, Black M, Hoeh W, Lutz R, Vrijenhoek R: DNA primers for amplification of mitochondrial Cytochrome c Oxidase subunit I from diverse metazoan invertebrates. Mol Mar Biol Biotechnol 1994, 3:294-299.

34. Hall TA: BioEdit: a user-friendly biological sequence alignment editor and analysis program for Windows 95/98/NT. Nucl Acids Symp Ser 1999, 41:95-98.

35. Clements AN: The Biology of Mosquitoes. Development, Nutrition and Reproduction. Volume I. London: Chapmann \& Hall; 1992.

36. Ow-Yang CF, Sta Maria FL, Wharton RH: Maintenance of a laboratory colony of Anopheles maculatus Theobald by artificial mating. Mosq News 1963, 23:34-35.

37. Motulsky HJ: Prism 5 Statistics Guide. GraphPad Software. San Diego CA: Inc; 2007. www.graphpad.com.
38. Lima JBP, Valle D, Peixoto AA: Adaptation of a South American malaria vector to laboratory colonization suggests faster-male evolution for mating ability. BMC Evol Biol 2004, 4:12.

39. Diabaté A, Dabire RK, Milongo N, Lehmann T: Evaluating the effect of postzygotic isolation between molecular forms of Anopheles gambiae (Diptera: Culicidae). J Med Entomol 2007, 44(1):60-64.

40. Pennetier C, Warren B, Dabiré KR, Russell IJ, Gibson G: "Singing on the Wing" as a mechanism for species recognition in the malaria mosquito Anopheles gambiae. Curr Biol 2010, 20:131-136.

41. Choochote $W$, Rongsriyam Y, Leemingsawat $\mathrm{S}$, Jitpakdi A, Komalamisra N, Surathin K, Somboon P, Chen B, Wongkamchai S, Jariyapan N,

Tippawangkosol P, Pitasawat B, Riyong D: Intraspecific hybridization of Anopheles minimus (Diptera: Culicidae) species A and C in Thailand. Southeast Asian J Trop Med Public Health 2002, 33(3):23-28.

42. Somboon P, Thongwat D, Somwang P, Teng HJ, Tsuda Y, Takagi M: The specific status of Anopheles minimus s.l. collected from Taiwan. Southeast Asian I Trop Med Public Health 2005, 36(3):605-608.

43. Kitzmiller JB, Frizzi G, Baker RH: Evolution and speciation within the maculipennis complex of the genus Anopheles. Genet Insect Vectors Dis 1967, 5:151-210. Elsevier Publishing Company.

44. Kitzmiller JB: Genetics, cytogenetics and evolution of mosquitoes. Adv Genet 1976, 18:316-433.

45. Coluzzi M: Sibling species in Anopheles and their importance in malariology. Misc Publ Entomol Sot Am 1970, 7:63-72.

46. Orr HA: The population genetics of speciation: the evolution of hybrid incompabilities. Genetics 1995, 139:1805-1813.

47. Orr HA: Haldane's rule. Ann Rev Ecol Syst 1997, 28:195-2018.

48. Coyne JA, Orr HA: Patterns of speciation revisited. Evolution 1997, 51:295-303.

\section{doi:10.1186/s13071-014-0559-6}

Cite this article as: Fontoura et al: Hybrid sterility in crosses between two Brazilian sibling species of the Anopheles albitarsis complex.

Parasites \& Vectors 2014 7:559.

\section{Submit your next manuscript to BioMed Central and take full advantage of:}

- Convenient online submission

- Thorough peer review

- No space constraints or color figure charges

- Immediate publication on acceptance

- Inclusion in PubMed, CAS, Scopus and Google Scholar

- Research which is freely available for redistribution 